\title{
EMOTIONAL REACTION TO MENARCHE AND MENSTRUAL ATTITUDES
}

\author{
Sandra Nakić Radoš \\ Department of Psychology, Catholic University of Croatia \\ Ilica 242, 10000 Zagreb \\ snrados@unicath.hr \\ Roberta Jelić \\ Primary School Ljudevit Gaj \\ Krstova 99, 31000 Osijek \\ rcrncic@gmail.com \\ Đurđica Jurjević \\ Primary School Starigrad \\ Jose Dokoze 30, 23244 Starigrad Paklenica \\ durdica.petresevic@skole.hr
}

\begin{abstract}
The goal of this study was to examine current attitudes toward menstruation in adolescent postmenarcheal girls in relation to age at menarche, time since menarche had occurred, preparedness, and emotional reaction to menarche.

Postmenarcheal adolescent girls from primary and secondary schools $(N=246)$ participated in the study, with an average age of 15.1 years and average age at menarche 12.4 years. Participants filled out the adapted version of Adolescent Menstrual Attitude Questionnaire (AMAQ; Marvan \& Molina, 2002), Expected/Experienced Emotions related to Menarche Scale (Emo-M; Nakić Radoš, Mužinić Bikić, \& Roso Perić, in press), Preparedness for the Menarche (PM; Rodriguez White, 2013), and Pubertal Development Scale (PDS; Petersen, Crockett, Richards, \& Boxer, 1988).

The two-way ANOVA showed that early maturers ( $\leq 11$ years at menarche) had significantly higher level of negative attitudes than average maturers (12 years) and late maturers ( $\geq 13$ years). Both early and average maturers had a higher level of secretive attitudes than late maturers. However, this effect was present only if menarche occurred in less than two years. Regression analyses showed that higher level of pleasant emotions at menarche predicted higher level of positive attitudes toward
\end{abstract}

\section{Acknowledgements:}

We thank Zrinka Mužinić Bikić and Ines Roso Perić for help with collecting data. 
menstruation (45.2\% variance explained). Lower age at menarche, less time from the menarche, and a higher level of unpleasant emotions at menarche predicted higher levels of secretive attitudes (35.1\% variance explained) and negative attitudes $(22.7 \%$ variance explained).

In conclusion, age at menarche, time for adaptation to menstruation, and initial emotional reaction to menarche are significant determinants of menstrual attitudes in adolescent girls. Education and preparing girls for menstruation at early stages of puberty is necessary.

Key words: menarche, menstruation, attitudes, emotions, puberty

Menarche is an important milestone in a girl's life and it signifies the beginning of fertility. Although menarche is the most prominent mark of puberty in girls, from the biological standpoint, it is better to look at menarche as a process in pubertal development, rather than as a stand-alone event. Adrenarche is the stage characterised by the increase in the adrenal activity which precedes puberty (van den Akker, 2012). About two years after the first signs of puberty, menarche appears, usually between 11 and 15 years (Bralić et al., 2012), but on average between 12 and 12.5 years (Keresteš, Brković \& Kuterovac Jagodić, 2010).

Menstruation is an integral part of girls' and women's everyday life and menstrual experience can be related to reproductive choices later in life. Attitudes toward menstruation are related to women's perception of their body. Female students who reported more negative and less open menstrual attitudes, thus reflecting their menstrual shame, also reported higher body shame, which was in turn related to engaging in riskier sexual behaviour (Schooler, Ward, Merriwether, \& Caruthers, 2005). Using a qualitative approach, Moloney (2010) showed similar results that menstrual shame was related to women's self-perception, which can have a negative impact on experience of childbirth later in life. These findings show the importance of menstrual attitudes and experiences for women's image of her body and reproductive health.

Menstrual attitudes and experiences can be shaped by an interplay of different factors, where the most prominent are age at menarche and the first menarcheal experience. Early age at menarche is related to feelings of fear and worry at menarche, while late age at menarche is related to feelings of excitement and happiness and less unpleasant emotions overall (Marván \& Alcalá-Herrera, 2014; Nakić Radoš et al., in press). Moreover, age is related not only to the first emotional experience at menarche, but is related to menstrual attitudes, as well. Early maturation is related to secretive attitudes toward menstruation, while late maturation is related to more positive attitudes toward menstruation. However, these patterns were not consistent in all adolescent girls and were present only in adolescents who got the menarche in less than two years (Marván \& Alcalá-Herrera, 2014). These results show that time from menarche is another factor affecting menstrual attitudes. Koff and Ri- 
erdan (1996) followed girls longitudinally from premenarche to postmenarche and showed that menstrual experience was affected by expectations and initial menarcheal experience. In a retrospective study, college women were divided according to their menarcheal experience into those who had positive experience and felt ready for menarche and those who had negative experience and felt unprepared. Women with negative menarcheal experience also reported a more negative menstrual attitude and more negative premenstrual mood changes than women who had positive menarcheal experience (McPherson \& Korfine, 2004). Also, there is an interplay between age at menarche, menstrual attitudes, and preparedness for menstruation, in that early maturers felt unprepared for the start of menstruation (Marván \& AlcaláHerrera, 2014). Girls who reported to be better prepared for menstruation reported a more positive attitude toward menstruation. Adolescent girls who knew what was going on when menarche occurred, were less prone to negative feelings and secrecy about menstruation (Marván \& Molina-Abolnik, 2012). Secrecy attitudes toward menstruation refer to keeping menstruation as a secret and embarrassment when talking about menstruation.

It has been shown that both positive and negative emotional reactions to menarche depend on menstrual attitudes, where perception of menstruation as negative event concurrently predicts more negative reactions to menarche, while perception of menstruation as a natural event predicts a more positive reaction to menarche (Tang, Yeung, \& Lee, 2003). However, the predictive value of emotional reactions at menarche for the current menstrual attitudes has been underinvestigated. McPherson \& Korfine (2004) did show retrospectively that current menstrual attitudes (menstruation as a debilitating event, a bothersome event, or a natural event) depends on the early menarcheal experience, either positive or negative. However, the important factor of age at menarche was not taken into account. Also, emotional reactions at menarche in previous studies were mainly assessed through check lists (Marván \& Alcalá-Herrera, 2014; Marván, Morales, \& Cortés-Iniestra, 2006; Tang et al., 2003), so their relation with menstrual attitudes was difficult to examine in multivariate statistical analysis. However, a new scale for measuring pleasant and unpleasant emotions separately (Nakić Radoš et al., in press) gives an opportunity to examine the predictive value of emotional reaction at menarche for menstrual attitudes.

The goal of this study was to examine current menstrual attitudes in adolescent postmenarcheal girls in relation to timing of the menarche, preparedness for the menarche, and recollection of emotions at menarche. Timing of the menarche was examined as the age at menarche and time since menarche had occurred. We expected that early maturers will have higher levels of negative and secretive attitudes, while late maturers will have higher level of positive attitudes. However, we expected this for girls who got menarche recently (in less than 2 years), only. Also, we wanted to examine how much preparedness for menarche and the recollection of the emotional reactions at menarche contribute to the explanation of menstrual attitudes. 
We expected that a higher level of preparedness and recollection of more pleasant emotional reaction at menarche contributes to more positive attitudes, while lower level of preparedness and recollection of more unpleasant emotional reaction at menarche contributes to higher level of secretive and negative attitudes.

\section{METHOD}

\section{Participants}

Two-hundred and forty-six postmenarcheal girls from primary $(N=116)$ and secondary schools $(N=130)$ participated in the study. The average age was 15.1 years $(S D=1.9$, range: $11.0-18.7)$ and average age at menarche was 12.4 years $(S D=1.15$; range: 9.1 years to 16.5 years). Average time from the occurrence of menarche to participation in the study was 2 years and 9 months $(S D=1.84)$.

Forty-four percent (44.3\%) of the sample reported that they were living in a rural area and 55.7\% in an urban area. Their mothers mainly graduated from secondary school (primary school: $8.9 \%$; secondary school: $73.6 \%$; college or university: $17.5 \%$ ), as well as their fathers (primary school: $10.6 \%$; secondary school: $72.0 \%$; college or university: $17.4 \%)$. Every other participant (50.4\%) reported that both of her parents were employed; only mother was employed for $27.3 \%$, only father was employed for $14.2 \%$, or none of the parents were employed for $8.1 \%$ of the participants. Regarding the perceived socioeconomic level, $4.5 \%$ of the participants perceived as living worse, $86.2 \%$ the same, and $9.3 \%$ better compared to their peers.

According to the age at menarche, the sample was divided into early maturers ( $\leq 11$ years; $n=68 ; 27.6 \%$ ), average maturers (12 years; $n=104 ; 42.3 \%$ ), and late maturers $(\geq 13$ years, $n=74 ; 30.1 \%)$. Also, the participants were divided by the time from the menarche into two groups: those who got the menarche in less than 2 years prior to participation in the study $(n=101 ; 41.1 \%)$ and those who got the menarche in more than 2 years $(n=145 ; 58.9 \%)$.

\section{Measures}

Adolescent Menstrual Attitude Questionnaire (AMAQ; Morse, Kieren, \& Bottorff, 1993) was administered to measure attitude toward menstruation. The AMAQ comprises 58 items and it has two forms, one for premenarcheal girls and one for postmenarcheal girls. Each item is rated on a five-point scale from 1 (completely disagree) to 5 (completely agree). In the current study, an adapted version of the AMAQ was used where the postmenarcheal form has 25 items and three subscales (Marván \& Molina, 2002). Positive Attitudes subscale has 10 items (sample item: "I am glad I have grown mature enough to menstruate"), Negative Attitudes has 9 
items (sample item: "Just the fact that I have my period makes me uncomfortable") and the Secrecy Attitudes has 6 items (sample item: "When I am having my period, I am scared that the boys will find out"). Cronbach's $\alpha$ for Positive, Negative, and Secrecy Attitudes were 0.88, 0.80, and 0.78, respectively (Marván \& AlcaláHerrera, 2014). The score for each subscale is divided by the number of items so the total possible range is from 1 to 5. The AMAQ was translated in Croatian by a translator and bi-lingual researcher. In the Croatian sample of adolescent postmenarcheal girls, the factor structure was not confirmed completely. According to the Confirmatory Factor Analysis (CFA) the following indices for the three-factor structure of the AMAQ were: $X^{2}(272)=645.39, p<0.001$; a Root Mean Square Error of Approximation (RMSEA) was 0.075 (90\% CI 0.067-0.082); a Comparative Fit Index (CFI) was 0.80; and Standardized Root Mean Square Residual (SRMR) was 0.081 . These indices were at the line of accepting the model (Kline, 2010), and given that factor loadings of three items on Negative Attitudes were below 0.3, and that internal consistency Cronbach $\alpha$ for the Negative Attitudes scale was 0.65 , the results of the Negative Attitudes subscale should be taken with precaution. All items on Positive and Secrecy Attitudes had high factor loadings, and the internal consistency for both subscales was 0.85 . Correlation between the three factors in the model were $r=-0.04$ between Positive and Negative Attitudes, $r=-0.06$ between Positive and Secrecy Attitudes, and $r=-0.78(\mathrm{p}<0.001)$ between Negative and Secrecy Attitudes.

Expected/Experienced Emotions related to Menarche Scale (Emo-M; Nakić Radoš et al., in press) is a 22 -item scale that measures pleasant and unpleasant emotions related to menarche. By modifying the instruction, it can be used in premenarcheal girls to assess their expected feelings once they get menarche or in postmenarcheal girls to assess their experienced emotions when they got menarche. In the current study, the latter instruction was used. Each item is rated on a 5-point scale (1-not at all to 5 - completely true for me). The Emo-M consists of two subscales, Pleasant Emotions (11 items) and Unpleasant Emotions (11 items). The total score for each subscale was divided with the number of items, resulting in a score from 1 to 5. The Cronbach's $\alpha$ was 0.91 and 0.86 for Pleasant and Unpleasant Emotions subscales, respectively.

Preparedness for the Menarche (PM; Rodriguez White, 2013) was measured by 7 items assessing feeling ready for menarche, having enough information about menstruation and knowing what to expect once when menstruation begins. Respondents rate each item on a five-point scale, from 1 (strongly disagree) to 5 (strongly agree). Total score is in the range from 7 to 35 where higher scores relate to higher levels of preparedness. The Cronbach's $\alpha$ coefficient in the original study was at the acceptable level of 0.72 (Rodriguez White, 2013). The PM questionnaire was translated into Croatian by a translator and bi-lingual researcher. In the current study, the CFA confirmed one-factor model with following indices: $X^{2}(14)=47.98, p<.001$; a 
RMSEA was 0.09 (90\% CI 0.07-0.13); a CFI was 0.95; and SRMR was 0.04. Cronbach's $\alpha$ coefficient was 0.87 .

Pubertal Development Scale (PDS) was developed by Petersen, Crockett, Richards, $\&$ Boxer (1988). Respondents report on physical changes characteristic for puberty on five items, with two items differing for boys and girls. The form for girls, which was used in the current study, comprises items that assess growth in height, growth of body hair, skin changes, growth of breasts, and menstrual status. Items are rated on a 4-point scale ( 1 - not yet started to 4 - seems complete), except for menstrual status item where "no menstruation" was scored with 1 point and "menstruating" was scored with 4 points. According to this question, the girls were divided to premenarcheal and postmenarcheal girls, of which only the postmenarcheal subsample was included in the current study. Total score on the PDS ranges from 5 to 20 . The PDS was validated for use with Croatian adolescents with Cronbach's $\alpha .79$ in a sample of girls (Keresteš et al., 2010). Cronbach's $\alpha$ was 0.79 in the current study, as well.

Demographic questionnaire sheet comprised questions on age (in years and months), grade, place of residence, maternal and paternal education level and their employment status. Perceived socioeconomic status was reported by item: "How does your family live compared to your peers' family? where possible answer options were worse, the same, or better.

\section{Procedure}

This study was part of a larger cross-sectional correlational study about psychological factors related to menstruation in adolescent girls from six primary and secondary schools in Croatia conducted in the school year 2014/2015 (Nakić Radoš et al., in press). First, an approval for study was obtained from the schools' committees and headmasters. Then, informed consent was collected from the female pupils and their parents. Those pupils who presented both informed consent forms could have participated in the study and anonymously fill out the booklet with the questionnaires during a class master lesson. Boys were asked to leave the classroom and girls that were absent from school on the survey day were not contacted.

\section{Statistical analysis}

Differences in the level of menstrual attitudes were tested with $3 \times 2$ ANOVA where the first independent variable was age at menarche (early/average/late maturers) and the second was time form the menarche (more/less than 2 years ago). The assumption of homogeneity of variance was obtained and ANOVA results were followed by Gabriel post hoc test. Pearson's correlation coefficient was used to ex- 
amine the associations between pubertal development, menarcheal emotional experience, preparedness for menarche, and menstrual attitudes. Moreover, to examine how much the emotional reactions and preparedness for menarche contribute to the explanation of menstrual attitudes, hierarchical regression analysis was used where pubertal timing was controlled for in the first step.

\section{RESULTS}

Descriptive statistics for pubertal development, preparedness for menarche, level of emotional reaction to menarche, and menstrual attitudes are presented in Table 1. On average, participants reported that they had been well prepared for

Table 1. Descriptive statistics for all variables and correlations between the pubertal timing, preparedness for menarche, level of emotional reaction to menarche, and menstrual attitudes

\begin{tabular}{|c|c|c|c|c|c|c|c|c|c|}
\hline & 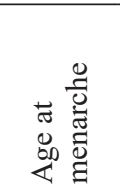 & 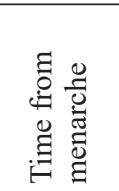 & $\stackrel{\mathscr{2}}{2}$ & 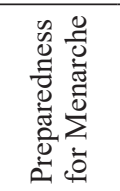 & 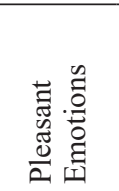 & 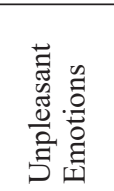 & $: \stackrel{\substack{0 \\
0}}{:}$ & 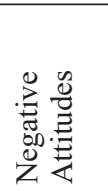 & 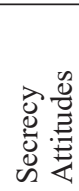 \\
\hline$M$ & 12.42 & 2.75 & 16.65 & 27.68 & 2.97 & 2.58 & 2.22 & 2.93 & 2.00 \\
\hline$S D$ & 1.12 & 1.84 & 2.19 & 6.29 & 0.98 & 0.89 & 0.73 & 0.64 & 0.92 \\
\hline $\begin{array}{l}\text { Age at } \\
\text { menarche }\end{array}$ & - & & & & & & & & \\
\hline $\begin{array}{l}\text { Time from } \\
\text { menarche }\end{array}$ & $-0.22 * *$ & - & & & & & & & \\
\hline PDS & 0.06 & $0.56 * *$ & - & & & & & & \\
\hline $\begin{array}{l}\text { Preparedness } \\
\text { for Menarche }\end{array}$ & $0.32 * *$ & $-0.28 * *$ & $-0.14^{*}$ & - & & & & & \\
\hline $\begin{array}{l}\text { Pleasant } \\
\text { Emotions }\end{array}$ & 0.11 & -0.02 & 0.05 & $0.25 * *$ & - & & & & \\
\hline $\begin{array}{l}\text { Unpleasant } \\
\text { Emotions }\end{array}$ & $-0.20 * *$ & 0.11 & -0.01 & -0.06 & $-0.26^{* *}$ & - & & & \\
\hline $\begin{array}{l}\text { Positive } \\
\text { Attitudes }\end{array}$ & 0.09 & 0.02 & 0.06 & $0.29 * *$ & $0.65 * *$ & $-0.22 * *$ & - & & \\
\hline $\begin{array}{l}\text { Negative } \\
\text { Attitudes }\end{array}$ & -0.11 & -0.11 & -0.09 & $-0.19^{* *}$ & -0.08 & $0.44 * *$ & -0.07 & - & \\
\hline $\begin{array}{l}\text { Secrecy } \\
\text { Attitudes }\end{array}$ & $-0.24 * *$ & $-0.46^{* *}$ & $-0.29 * *$ & $-0.39 * *$ & -0.12 & $0.31 * *$ & -0.06 & $0.46^{* *}$ & - \\
\hline
\end{tabular}

Note: ${ }^{*} p<0.05 ; * * p<0.01$. PDS - Pubertal Development Scale. 


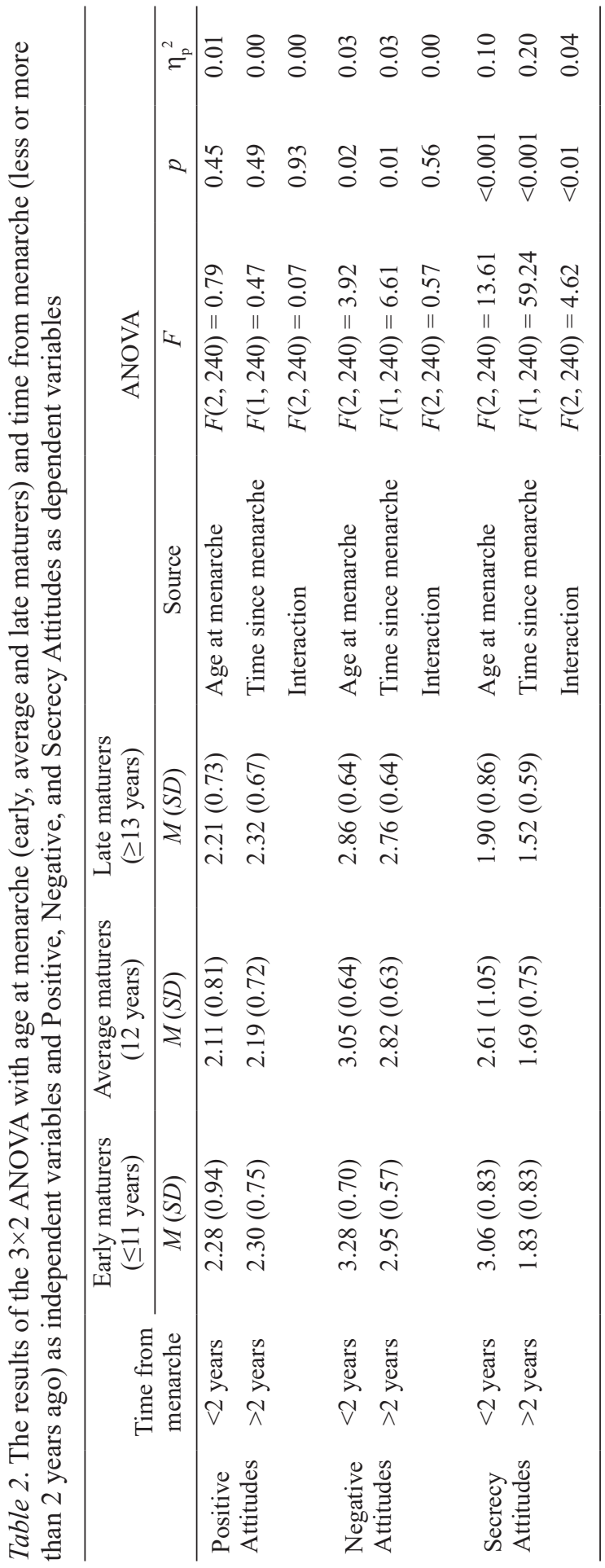


menarche, experienced a moderate level of both pleasant and unpleasant emotions when menarche occurred, had lower levels of both positive and secretive attitudes, and average level of negative attitudes.

The $3 \times 2$ ANOVA showed the significant main effects of both age at menarche and time since menarche on negative and secretive attitudes, but not on positive attitudes (Table 2). Post-hoc tests showed that early maturers had significantly higher levels of both negative and secretive attitudes. However, it is interesting to point out that higher levels of secrecy was reported by both early and average maturers. Adolescent girls who got menarche less than two years ago, also reported more negative and secretive attitudes than girls who got menarche more than two years ago. There was also significant interaction of age at menarche and time since menarche for secretive attitudes, showing that only early and average maturers who got menarche in less than two years had higher level of secrecy, while those who got menarche in more than two years had lower level of secrecy irrespective of the age at menarche (Figure 1).

Correlations between pubertal timing, the level of emotional reactions to menarche, preparedness for menarche, and menstrual attitudes were examined (Table

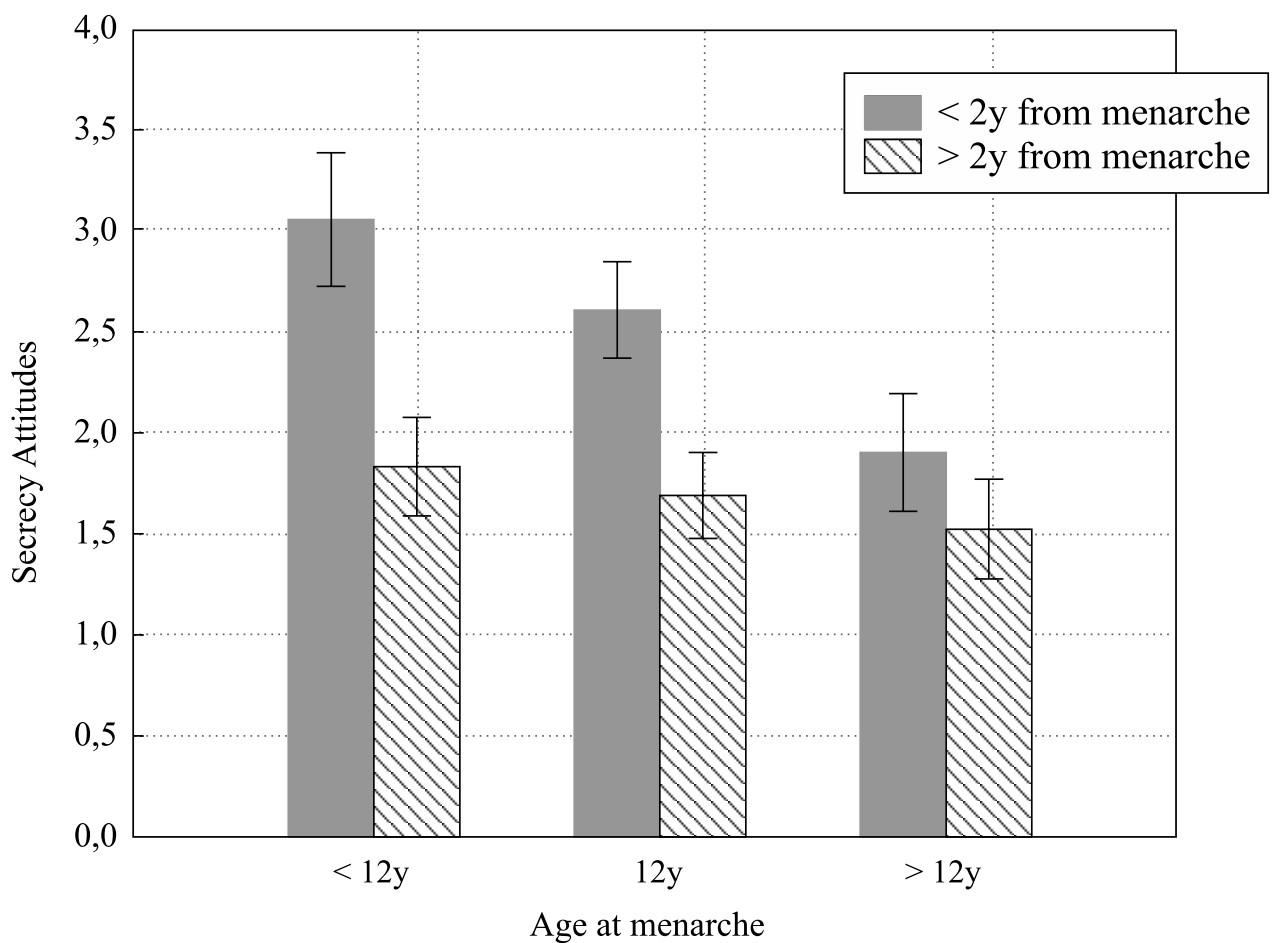

Figure 1. Secrecy Attitudes in respect to the age at menarche and time from menarche 


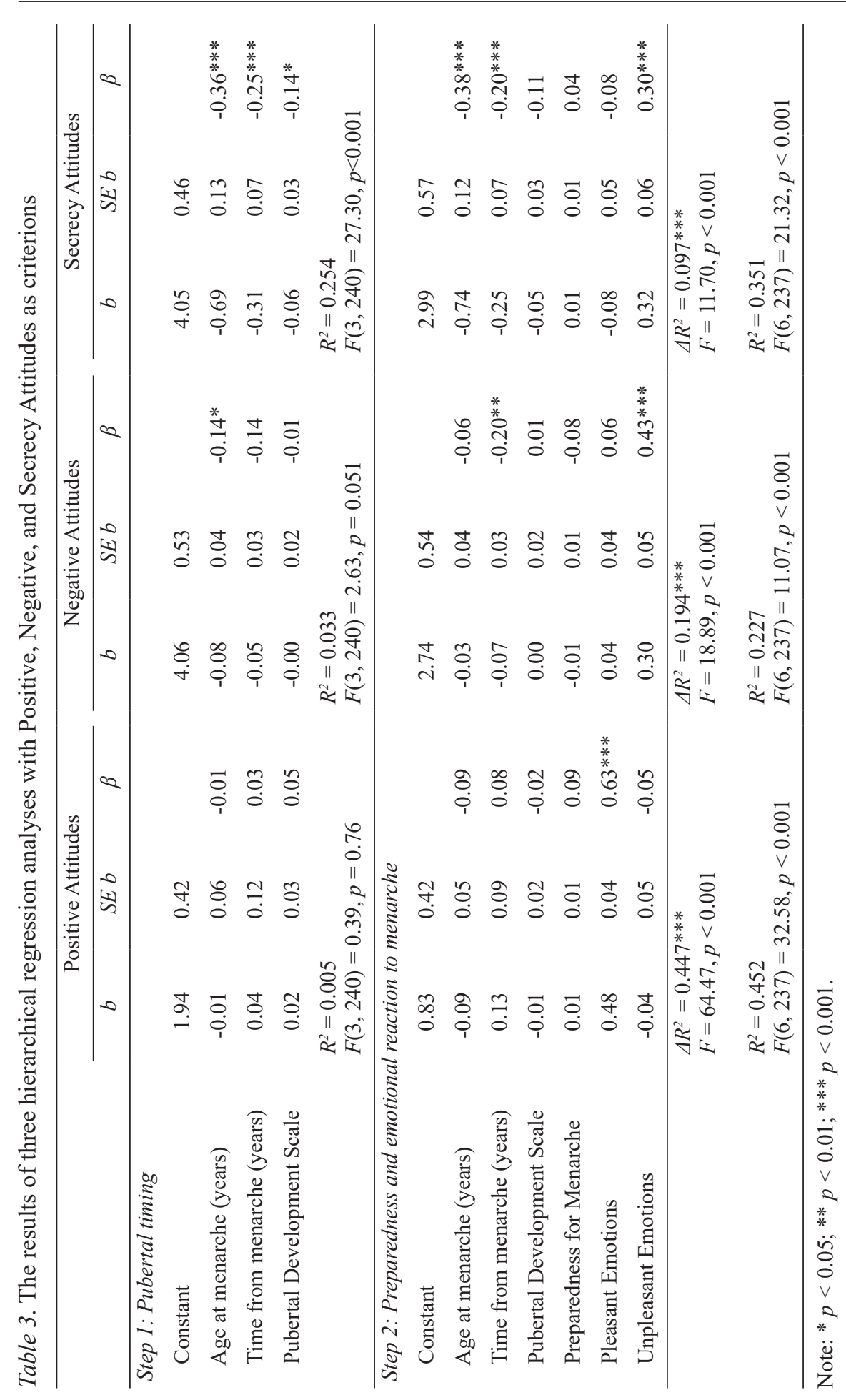


1). Pubertal timing was not related to positive nor negative attitudes, but was only related to secretive attitudes. Similarly to previously reported results, a higher level of secrecy was related to younger age at menarche, recent menarche, and lower level of pubertal development. Menstrual attitudes were related to emotional reaction at menarche and preparedness for menarche. Namely, higher levels of positive menstrual attitudes were related moderately to higher levels of positive emotions, weakly to lower levels of unpleasant emotions, and weakly to preparedness for menarche. Higher levels of both negative and secretive attitudes were weakly related to higher levels of unpleasant emotions and lower levels of preparedness for menarche. Also, inspection of the relations between other variables showed that a higher level of preparedness was related to higher age at menarche and a higher level of pleasant emotions, but not related to unpleasant emotions.

Three hierarchical regression analyses with positive, negative, and secretive attitudes as criteria were performed (Table 3 ). After controlling for pubertal timing in the first step which explained a small proportion of variance of both positive and negative attitudes, emotions at menarche and preparedness for menarche explained a significant proportion of additional variance. The $45.2 \%$ of the variance of positive attitudes was explained with pleasant emotional reaction as a significant predictor $(\beta$ $=0.63, p<0.001)$. Only $22.7 \%$ of the variance of negative attitudes was explained, where unpleasant emotions $(\beta=0.43, p<0.001)$ and shorter time from menarche $(\beta=-0.20, p<0.01)$ were significant predictors. On the other hand, for secretive attitudes, pubertal status explained $25.4 \%$ of the variance in the first step, while preparedness and emotional reactions explained additional $9.7 \%$ of the variance in the second step. Higher level of secrecy could be predicted by lower age at menarche $(\beta=-0.38, p<0.001)$, shorter time period from the menarche and higher level of unpleasant emotional reaction at menarche $(\beta=-0.30, p<0.001)$.

\section{DISCUSSION}

The results showed that menstrual attitudes are shaped by pubertal timing and initial emotional reaction at menarche. Pubertal timing had a significant effect on both negative and secretive attitudes, where girls of younger age at menarche who got menarche recently reported significantly higher level of both negative and secretive attitudes, as expected. This implies that there is a period of adaptation to menstruation, when girls are embarrassed to talk and ask about menstruation and do not want others to know about their menstruation. It is interesting to point out that this period of secrecy is present not only in early maturers, but in average maturers, as well. Menarche occurred around 12.5 years in the current sample, similar to the previous study (Keresteš et al., 2010) and although it is normative that menarche occurs at a certain age, it is still not normative to talk about menstruation at that age. These results are partially in line with the expectations and previous findings. 
Namely, we expected that late maturers will have more positive attitudes, but in our sample, there was no difference in positive attitudes in respect to age at menarche. In comparison, Marván and Alcalá-Herrera (2014) showed that among Mexican adolescent girls those of early maturation had more negative menstrual attitudes and those of late maturation had more positive attitudes. However, this discrepancy between early and late maturers diminished if menarche occurred more than two years ago. Similar to the latter study, our findings also showed that the period of two years had a significant effect on menstrual attitudes, after which the difference in negative and secretive attitudes between early, average, and late maturers diminishes.

Previous studies showed that age at menarche had an effect both on the initial menarcheal experience and attitudes toward menstruation (Marván \& Alcalá-Herrera, 2014). Also, it was shown that the initial menarcheal experience and current menstrual attitudes were related (Erbil, Fele, \& Karakaşli, 2015; McPherson \& Korfine, 2004), and that initial menarcheal experience can be predicted by menstrual attitudes (Tang et al., 2003). In line with these findings, we found the relation between the initial emotional reaction to menarche and current menstrual attitudes. The findings of this study contribute to the scarce literature on this topic in that it was shown that, even after controlling for timing of menarche, the initial emotional reaction to menarche predicts menstrual attitudes. Pleasant initial emotional reaction to menarche predicts positive attitudes, whereas unpleasant emotional reaction predicts both negative and secretive attitudes.

It is important to take preparation for menarche into account given that early maturers have less time to prepare for menarche. One in five girls feels prepared for menstruation, and this percent is even lower in early maturers (Marván \& AlcaláHerrera, 2014). Early maturers, on average, experience more unpleasant emotions of fear, worry, and sadness when menarche occurs, while late maturers experience more pleasant emotions of excitement and happiness (Marván \& Alcalá-Herrera, 2014; Nakić Radoš et al., in press). In a retrospective study, women of different ages reported that those of them who did not know about menstruation before menarche were more scared at menarche, while women who did know about menstruation before menarche felt more calm (Marván et al., 2006). The preparedness for menstruation was shown as an important factor related both to initial emotional reaction and menstrual attitudes (Marván \& Alcalá-Herrera, 2014; Marván, Molina-Abolnik, 2012). The results of our study showed that lower preparedness for menarche is related to younger age at menarche, lower level of pleasant emotions at menarche and positive menstrual attitudes, and higher level of negative and secretive attitudes. However, preparedness was not predictive for current menstrual attitudes, because emotions and pubertal timing were more significant predictors. We can speculate that low preparedness and early maturation shape the initial emotional reaction to menarche, which in turn shape current menstrual attitudes. However, this should be further examined in future studies with more complex analysis. 
Also, it is interesting to see how both expectations and initial attitudes toward menstruation are shaped. Expectations and knowledge about menarche are not driven by information on physiological process only, but also by sociocultural influences, such as peers' comments about menarche, hearing adult's conversations, seeing the older sister going through the process etc. (do Amaral, Hardy, \& Hebling, 2011; Orringer \& Gahagan, 2010). The most common source of information about menstruation in different counties has been the mother (Ali \& Rizvi, 2010; Marván $\&$ Molina-Abolnik, 2012). However, mother's attitudes toward menstruation do not exclusively affect the adolescent daughter's attitudes. Study conducted with adolescents and their peers and mothers from 30 years ago showed that mothers had more positive attitude toward menstruation than their daughters. Adolescents viewed menstruation as more debilitating and bothersome and less as a positive event. Also, it appeared that adolescent girls had more similar attitudes as their peers than their mothers (Stoltzman, 1986).

Several limitations of this study should be considered. Firstly, this was a retrospective study so decisive conclusion on the direction of the relation between menarcheal experience and menstrual attitudes cannot be made. It is possible that these attitudes were shaped before menarche and thus influenced the menarcheal experience, or yet that different menarcheal experience further affects menstrual attitudes. Also, changed recollection of the initial menarcheal experience based on current experience cannot be excluded, given that on average menarche occurred 2 years and 9 months before participating in the study. Future studies would therefore benefit from a longitudinal design with several measurements which could then show the role of initial menstrual attitudes for emotional experience at menarche and then to examine their interplay for menstrual attitudes later through adolescence. Furthermore, Negative Attitudes subscale of the AMAQ had lower reliability than is recommended, so the results regarding negative attitudes should be taken with caution. Some of the items in the Negative Attitudes subscale refer to one's opinion that girls should be spared while having a period (spared from a gym, school etc.) so there is a possibility that subscale could be further split into different aspects of negative attitudes. However, the results for negative attitudes are rather similar to the results for secretive attitudes, so it gives us confidence in their validity. Next issue is related to splitting the sample according to time from menarche has occurred into less or more than two years ago, which was made in accordance with a previous study (Marván \& Alcalá-Herrera, 2014). However, this line is arbitrary and future studies should examine what time period exactly is necessary for negative attitudes and secrecy to decrement after menarche occurs.

Despite these limitations, findings from this study are useful and could have practical implications for designing psychoeducational classes and workshops for girls. Given that this study showed that early maturers had more negative and secretive attitudes, it is necessary to apply psychoeducation earlier in puberty. Although girls become more focused on their body and bodily changes when they enter pu- 
berty (Bearman, Presnell, Martinez \& Stice, 2006), they may be embarrassed to talk about these changes. As the results showed, the beginning of puberty is characterised by secrecy about menstruation. Therefore, information about menstruation given in schools should be well prepared and, preferably, given in classes when only girls are present. In this way, they might feel more welcome to ask questions and share experiences. Also, parents, especially mothers who are mostly the first person girls will turn to (Marván \& Alcalá-Herrera, 2014), should be encouraged to talk with their daughters about menstruation before it occurs. Both family and school setting should engage around this topic to prepare girls for the upcoming natural event and help them feel positive about menstruation, which in turn can have an effect on their body image and be beneficial for their later reproductive health.

\section{REFERENCES}

Ali, T. S., \& Rizvi, S. N. (2010). Menstrual knowledge and practices of female adolescents in urban Karachi, Pakistan. Journal of Adolescence 33, 531-541.

Bearman, S. K., Presnell, K., Martinez, E., \& Stice, E. (2006). The skinny on body dissatisfaction: A longitudinal study of adolescent girls and boys. Journal of Youth and Adolescence, 35(2), 217-229.

Bralić, I., Tahirović, H., Matanić, D., Vrdoljak, O., Stojanović Špehar, S., Kovačić, V., Blažeković-Milaković, S. (2012). Association of early menarche age and overweight/obesity. Journal of Pediatric Endocrinology and Metabolism, 25(1-2), 57-62.

do Amaral, M. C., Hardy, E., Hebling, E. M. (2011). Menarche among Brazilian women: memories of experiences. Midwifery, 27, 203-208.

Erbil, N., Felek, N., \& Karakaşl1, E. (2015). The relationship between attitudes towards menarche and current attitudes towards menstruation of women: A comparative study. Journal of Human Sciences, 12(2), 1120-1130.

Keresteš, G., Brković, I., \& Kuterovac Jagodić, G. (2010). Prikladnost nekoliko subjektivnih mjera pubertalnoga sazrijevanja za primjenu u nekliničkim istraživanjima razvoja adolescenata [Suitability of several subjective measures of pubertal maturation for application in non-clinical research on adolescent development]. Društvena istraživanja, 19(6), 1015-1035.

Kline, R. B. (2010). Principles and practice of structural equation modeling. London: The Guilford Press.

Koff, E., \& Rierdan, J. (1996). Premenarcheal expectations and postmenarcheal experiences of positive and negative menstrual related changes. Journal of Adolescent Health, 18, 286-291.

Marván M. L., \& Alcalá-Herrera V. (2014). Age at menarche, reaction to menarche and attitudes towards menstruation among Mexican adolescent girls. Journal of Pediatric and Adolescent Gynecology, 27(2), 61-66.

Marván, M. L., \& Molina, M. (2002). Validacion en Mexico de un cuestionario de actitudes hacia la menstruacion dirigido a adolescents posmenarcas [Validation of a questionnaire of attitudes toward menstruation in post-menarche adolescents in Mexico]. Psicologia y Salud, 12(2), 173-178. 
Marván M. L., Molina-Abolnik, M. (2012) Mexican adolescent's experience of menarche and attitudes toward menstruation: Role of communication between mothers and daughters. Journal of Pediatric and Adolescent Gynaecology, 25, 358-363.

Marván, M. L., Morales, C., \& Cortés-Iniestra, S. (2006). Emotional reactions to menarche among Mexican women of different generations. Sex Roles, 54, 323-330.

McPherson, M. E., \& Korfine, L. (2004). Menstruation across time: menarche, menstrual attitudes, experiences and behaviors. Women's Health Issues, 14, 193-200.

Moloney, S. (2010). How menstrual shame affects birth. Women and Birth, 23, 153-159.

Morse, J. M., Kieren, D., \& Bottorff, J., (1993.) The adolescent menstrual attitude questionnaire, part I: Scale construction. Health Care for Women International, 14(1), 39-62.

Nakić Radoš, S., Mužinić Bikić, Z., \& Roso Perić, I. (in press). Psychometric properties of the Expected/Experienced Emotions related to Menarche Scale. Book of Selected Proceedings of the 20th Psychology Days in Zadar (Accepted for publication).

Orringer, K., \& Gahagan, S. (2010). Adolescent girls define menstruation: A multiethnic exploratory study. Health Care for Women International, 31(9), 831-847.

Petersen, A. C., Crockett, L., Richards, M., \& Boxer, A. (1988). A self-report measure of pubertal status: reliability, validity, and initial norms. Journal of Youth and Adolescence, $17,117-133$

Rodriguez White, L. (2008). Newly postmenarcheal adolescents' understanding of menarche and menstruation across race and income level as defined by qualification status for free or reduced lunches (Unpublished doctoral dissertation). University of Pittsburgh, Pittsburgh.

Rodriguez White, L. (2013). The function of ethnicity, income level, and menstrual taboos in postmenarcheal adolescents' understanding of menarche and menstruation. Sex Roles, 68, 65-76.

Schooler, D., Ward, L. M., Merriwether, A., \& Caruthers, A.S. (2005). Cycles of Shame: Menstrual shame, body shame, and sexual decision-making. The Journal of Sex Research, 42(4), 324-334.

Stoltzman, S. M. (1986). Menstrual attitudes, beliefs, and symptom experiences of adolescent females, their peers, and their mothers. Health Care for Women International, 7(1-2), 97-114.

Tang, C. S. K., Yeung, D. Y. L., \& Lee, A. M. (2003). Psychosocial correlates of emotional responses to menarche among Chinese adolescent girls. Journal of Adolescent health, 33, 193-201.

Van den Akker, O. B. A. (2012). Reproductive Health Psychology. London: Wiley-Blackwell. 


\title{
EMOCIONALNA REAKCIJA NA MENARHU I STAVOVI PREMA MENSTRUACIJI
}

\begin{abstract}
Sažetak
Cilj ovog istraživanja bio je ispitati stavove o menstruaciji kod postmenarhalnih adolescentica u odnosu na dob javljanja menarhe, vrijeme otkako se javila menarha, pripremljenost te emocionalnu reakciju na menarhu.

U istraživanju su sudjelovale postmenarhalne djevojke iz osnovnih i srednjih škola $(N=246)$ prosječne dobi 15,1 godina te prosječne dobi javljanja menarhe 12,4 godina. Sudionice su ispunile adaptiranu verziju Upitnika stavova prema menstruaciji za adolescentice (AMAQ; Marván \& Molina, 2002), Upitnik očekivanih/doživljenih emocionalnih reakcija na menarhu (Emo-M; Nakić Radoš, Mužinić Bikić i Roso Perić, u tisku), Pripremljenost na menarhu (PM; Rodriguez White, 2013) te Skalu pubertalnog razvoja (PDS, Pedersen i sur., 1988).

Dvosmjerna ANOVA je pokazala da rano sazrele djevojke (menarha s 11 godina $i$ prije) imaju značajno više negativnih stavova prema menstruaciji od prosječno (12 godina) i kasno sazrelih djevojaka (13 godina i kasnije). I rano i prosječno sazrele djevojke imaju više tajnovitih stavova prema menstruaciji od kasno sazrelih djevojaka. Međutim, ovaj efekt je prisutan samo kod djevojaka koje su dobile menarhu prije manje od dvije godine. Regresijske analize su pokazale da je viši intenzitet ugodnih emocija prediktor višeg intenziteta pozitivnih stavova prema menstruaciji (objašnjeno 45,2\% varijance). Niža dob pri javljanju menarhe, kraći period otkad se menarha javila te viši intenzitet neugodnih emocija predviđaju viši intenzitet tajnovitih (objašnjeno 35,1\% varijance) i negativnih stavova prema menstruaciji (objašnjeno $22,7 \%$ varijance).

Zaključno, dob pri menarhi, vrijeme za adaptaciju na menstruaciju te emocionalna reakcija na menarhu su značajne odrednice menstrualnih stavova kod adolescentica. Potrebno je educirati i pripremiti djevojke za menstruaciju u ranim stadijima puberteta.
\end{abstract}

Ključne riječi: menarha, menstruacija, stavovi, emocije, pubertet 